\author{
Available online at JECE (Journal of Early Childhood Education) \\ Website: http://journal.uinjkt.ac.id/index.php/jece \\ Permalink/DOI: http://dx.doi.org/10.15408/jece.v2i2.18745 \\ JECE, 2 (2), Desember 2020, 183-196
}

\title{
FATHER'S INVOLVEMENT IN PARENTING CHILDREN WITH CEREBRAL PALSY
}

\author{
Yubaedi Siron, Hana Sausan Ningrum, Lingga Gustiani, Fauziah Muaz \\ Universitas Islam Negeri Syarif Hidayatullah Jakarta \\ Corresponding e-mail: yubaedi.siron@uinjkt.ac.id
}

\begin{abstract}
Cerebral palsy children need special treatment from their parents. The optimal caring from father has a significant influence on the development of children with cerebral palsy. This study aims to explore the role of fathers in caring for children with cerebral palsy. This research uses a qualitative approach. This study uses semi-structured interviews with fathers who have children with cerebral palsy. The results of this study found that fathers play an active role in childcare. Fathers help build good relationships with children by inviting them to play, sing, and read a child's favourite storybook. Even though he is busy at work, the father always tries to fulfil the children's needs such as bathing, eating, giving medication, changing diapers and routine therapy. Each participant in this study had their parenting challenges. Although sometimes the participants feel unwilling to do therapy on children, what makes them enthusiastic is their high expectations.
\end{abstract}

Keywords : cerebral palsy; paternal involvement; parenting

\begin{abstract}
Abstrak
Anak cerebral palsy perlu pengasuhan yang berbeda dari orang tuanya. Peran ayah dalam pengasuhan anak cerebral palsy yang dilakukan secara optimal mampu memberikan pengaruh yang besar dalam perkembangan anak cerebral palsy. Penelitian ini bertujuan untuk menggali tentang peran ayah dalam mengasuh anak cerebral palsy. Penelitian ini menggunakan pendekatan kualitatif. Peneliti memperoleh informasi dengan menggunakan wawancara semi terstruktur kepada para ayah yang memiliki anak dengan cerebral palsy. Hasil dari penelitian ini didapatkan bahwa ayah berperan aktif dalam pengasuhan anak. Ayah turut membangun hubungan yang baik dengan anak seperti mengajaknya bermain, bernyanyi, serta membacakan sebuah buku cerita favorit anak. Walaupun ditengah kesibukannya dalam bekerja, ayah selalu berusaha membantu memenuhi kebutuhan anak seperti mandi, makan, memberikan obat, mengganti popok dan terapi rutin. Setiap partisipan dalam penelitian ini mempunyai tantangan pengasuhan masing masing. Walaupun terkadang partisipan merasa berat hati untuk melakukan terapi pada anak, namun yang membuat mereka semangat adalah harapan mereka terhadap anak-anaknya yang begitu besar.
\end{abstract}

Keywords : cerebral palsy; keterlibatan ayah; pengasuhan 


\section{Introduction}

Children with cerebral palsy are special so they need special treatment from their parents (Eliyanto \& Hendriani, 2013). In Indonesia, according to the Basic Health Research conducted by the Ministry of Health of the Republic of Indonesia in 2010, the percentage of children aged 24-59 months with cerebral palsy is $0.09 \%$ (WHO, 2013). Parents have an essential role in developing children (Hill \& Craft, 2003; Keown \& Palmer, 2014; Paul, Hart, Augustin, Clarke, \& Pike, 2020). The role of fathers in optimal parenting can significantly influence children's development (Appl, Brown, \& Stone, 2008; Crespi \& Ruspini, 2015; Frank, Keown, \& Sanders, 2014). The active participation of the father, which is carried out continuously from the aspects of time, initiative, and personal empowerment in all aspects of development, is essential for children such as physical, emotional, social, spiritual, moral, and intellectual aspects (Cabrera, Tamis-LeMonda, Bradley, Hofferth, \& Lamb, 2000; Paul et al., 2020). Parents who have cerebral palsy children have a significant role as child educators. The presence of a child with cerebral palsy is not what parents want. Some parents even experience despair over their presence (Siron, Perdana, Saputri, \& Hanifah, 2020). Successful communication in children with cerebral palsy requires parental involvement. Parents' responsibility also determines the successful development of children with cerebral palsy (Anindita \& Apsari, 2020; Pradipta \& Andajani, 2017; Whittingham, Sanders, McKinlay, \& Boyd, 2013; Yuliyati, 2014).

Fathers involved in parenting make children have good social and cognitive abilities; children also have good self-confidence (Parmanti \& Purnamasari, 2015). Fathers have a role in creating a peaceful atmosphere and providing opportunities for arguments for children. Fathers have an essential role in allowing children to do something, caring, provide support, and feel safe. Children with fathers who are actively involved in parenting will have good cognitive and social abilities and have a high sense of trust (Aisyah, Riana, \& Putri, 2019; Appl et al., 2008; Astuti \& Masykur, 2015). Fathers are expected to be actively involved in direct interactions with children (Appl et al., 2008). Involving fathers in childcare from infancy positively affects their development (Crespi \& Ruspini, 2015; Frank et al., 2014; Li \& Fleer, 2015; Siron, 2019). This condition can be seen when a father gives his children love; their child will be close to his father. Besides, the father and son will grow to be more gentle and expressive (Appl et al., 2008; Frank et al., 2014; Putnick et al., 2012).

Fathers can play a role in parenting and participating in children's daily activities (Appl et al., 2008; Erawati, 2009b; Keown \& Palmer, 2014). The policies that previously focused on mothers began to provide opportunities and space for father figures to express themselves in the parenting process (Crespi \& Ruspini, 2015; Hidayati, Kaloeti, \& Karyono, 2011; Keown \& Palmer, 2014). According to (Aisyah et al., 2019) (Aisyah et al., 2019), fathers' role in parenting is divided into direct 
interaction, interaction with children when needed and responsibilities that are not involved in direct interaction with children. Father involvement is about building positive interactions and paying attention to children's development by providing comfort and closeness (Allen \& Daly, 2007). A good relationship with a father indicates understanding and accepting their child's presence (Putnick et al., 2012; Rohner, 2014; Whittingham et al., 2013). The father's involvement also helps build empathy, love each other, and have good social relationships. Fathers also make significant contributions to children's development. The experience that the child experiences with the father will affect a child to adulthood later. The father's role and parenting behaviour affect the child's development and well-being and the transition to adolescence (Cabrera et al., 2000; Frank et al., 2014; Li \& Fleer, 2015).

The father's involvement is equally essential for the child with cerebral palsy (Siron et al., 2020). Cerebral palsy disorders are characterized by motor neurological disorders in the child's brain. Cerebral palsy disorders usually occur in prenatal, natal and postnatal (Rosenbaum P, Paneth N, Leviton A, 2007). Therefore, people with cerebral palsy need treatment in meeting their daily needs, such as bathing, eating and walking (Septiningsih \& Cahyanti, 2014).

According to data held by the World CP Day Committee in Australia, 1 in 3 children with cerebral palsy cannot walk. 1 in 4 children with cerebral palsy cannot speak, 3 out of 4 children with cerebral palsy experience pain, 1 in 4 children with Cerebral Palsy has epilepsy. 1 in 4 children with cerebral palsy have behavioral problems, 1 in 2 children with cerebral palsy have intellectual impairment, 1 in 10 children with cerebral palsy have severe vision problems. 1 in 4 children experience defecation control disorders, and 1 in 5 children have sleep disturbances. Lastly, 1 in 5 children with cerebral palsy has trouble controlling saliva. Children with cerebral palsy are more at risk of having seizures, although the CP Day committee's data states that 1 in 4 children with cerebral palsy has epilepsy (Rovasita, 2017).

In the well-being psychological research in a single father with children with cerebral palsy, it was found that mothers have an essential role in caring for children with special needs, but the role of fathers is also essential (Septiningsih \& Cahyanti, 2014). A single father needs to divide his time between earning a living and raising children with special needs. Also explained in the research on fathers' involvement in childcare (Astuti \& Masykur, 2015), fathers are expected to work together in carrying out various roles, are accustomed to doing domestic tasks, and not rigid in the division of tasks between husband and wife.

Unfortunately, a father is usually rarely seen taking care of his children because of his busy work, so it is not uncommon for a father figure to look strange. A father's involvement is needed to build a positive relationship between father and son (Diadha, 2015; Erawati, 2009a; Keown \& Palmer, 2014), especially for children 
with cerebral palsy. Children with cerebral palsy disorders need the father's role to continue to provide support and encouragement to children. Generally, a father who has a child with cerebral palsy initially considers that caring for a child with cerebral palsy is not an easy thing so that sometimes there is internal anxiety(Varan, Rohner, \& Eryuksel, 2008; Whittingham et al., 2013).

Given the importance of the father's role in children's care with cerebral palsy, the best practice form of paternity in children with cerebral palsy needs to be explored more deeply. This study aims to provide an overview of how fathers are actively involved in caring for children with cerebral palsy.

\section{Method}

This study used a qualitative approach to describe the role of fathers who have children with cerebral palsy. The stages of this research were instrument preparation, resource search, interviews, and data processing. The data collection technique used in this study was to use interviews. This study involved three fathers who have children with cerebral palsy. Participant 1, father 30 years old, three years old child, works as an entrepreneur and domiciled in South Lampung. Participant 2, father 33 years, age 6 years 6 months, work as a private employee and domiciled in Bandar Lampung. Participant 3, father 35 years, age 9 years 11 months, works as a private employee and resides in Cikarang, Bekasi.

Table 1. Research Participant Data

\begin{tabular}{llll}
\hline No. & Father & Father's age & Children's Age \\
\hline 1 & N1 & 30 years & 3 years \\
\hline 2 & N2 & 33 years & 6 years 6 months \\
\hline 3 & N3 & 35 years old & 9 years 11 months \\
\hline
\end{tabular}

The interview instrument is the structured interview and consulted with experts before being used to collect data. Interviews conducted online to explore the experiences of 3 fathers in raising children with cerebral palsy.

Table 2. Interview Guidelines

\begin{tabular}{ll}
\hline No. & Question Guide \\
\hline 1 & Activities that are usually done by father and son \\
\hline 2 & The way the father divides his time between work and upbringing \\
\hline 3 & The way the father divides his time between work and upbringing \\
\hline 5 & Type of communication carried out by father and son \\
\hline 6 & The way the father is actively involved in meeting the daily needs of the child \\
\hline 8 & The way dad responds to other people's comments \\
\hline 9 & The way the father teaches children with cerebral palsy \\
\hline 10 & The way the father calms the child if something happens to the child \\
\hline
\end{tabular}


In this study, data analysis used (Miles \& Huberman, 1994) by reducing data, verifying data, and displaying data. The data analyze at 3 stages, data reduction, display data, and conclusion (drawing/verifying data). Data reduction in this study focuses on data by the theme and provides codes for each aspect. All data classified according to the focus of the study.

The next stage is data presentation. The presentation of the data in this study intends to find meaning from the data obtained, then arranged systematically, from complex to simple but selective forms of information. Lastly is conclusion and verification. Conclusion in this research described in stages: a) check data representation; b) checking data on the influence of researchers; c) make data comparisons; d) use extreme cases in interpreting negative data. This study code the participant using n1, n2, n3 for initializing father as a participant to display the data.

\section{Results and Discussion}

Globally, studies related to father involvement measured several variations, such as paternal involvement, father involvement, and fathering quality. Most studies measure it by breaking down the variable of father involvement into more $\mathrm{d}$

etailed indicators, for example, father support, father rigid control (paternal of disciplining children, paternal firm control), paternal didactic interaction, paternal of social activities, paternal of responsibility, paternal acceptance, child's time directly with father only (an activity with father, time with father), relationship quality, talking with father, the significance of father, father monitoring, father presence, nurturant fathering, dan expressive (Appl et al., 2008; Crespi \& Ruspini, 2015; Erawati, 2009b; Filus \& Roszak, 2014; Frank et al., 2014; Li \& Fleer, 2015; Rohner, 2014).

This study coded the data into several categories that focused on fathers' involvement in parenting cerebral palsy. In the first category discussing the activities that fathers usually do with their children, fathers play an active role in fulfilling their needs, such as eating, bathing, routine medicine, therapy, and playing. (Septiningsih \& Cahyanti, 2014) stated that people with cerebral palsy need treatment to fulfil their daily needs, such as bathing, eating, and walking.

Table 3. Activities that are usually carried out by fathers with children

\begin{tabular}{lll}
\hline Category 1 & Code & Quote \\
\hline $\begin{array}{l}\text { Activities that are usually } \\
\text { done by father and son }\end{array}$ & $\begin{array}{l}\text { Fulfil daily activities, therapy } \\
\text { and stretching (n1) }\end{array}$ & $\begin{array}{l}\text { Eating, bathing, taking } \\
\text { medication in routine, therapy } \\
\text { play, stretching. }\end{array}$ \\
\cline { 2 - 3 } & $\begin{array}{l}\text { Playing } \\
\text { (n2) }\end{array}$ & $\begin{array}{l}\text { Playing ball, driving car around } \\
\text { Listening to music, praying and }\end{array}$ \\
\hline
\end{tabular}

Vol. 2 No. 2 | $187-196$ 
playing games

(n3) together, and playing games

together

In the second category, it discusses how fathers distribute their time between work and care. The three participants helped the wife's role in helping with domestic activities, bathing, and accompanying children before or after work. As stated by (Astuti \& Masykur, 2015), fathers will work together in carrying out various roles, are accustomed to doing domestic tasks, and are not rigid in the distribution of tasks between husband and wife. The synergy between father and mother contributes positively to the child's development(Dyches \& Smith, 2017; Jeong \& Kim, 2016; Keown \& Palmer, 2014; McFarland-Piazza \& Saunders, 2012; Moss, 2012).

Table 4. How fathers divide their time between work and care

\begin{tabular}{lll}
\hline Category 2 & Code & Quote \\
$\begin{array}{l}\text { The way the father divides his } \\
\text { time between work and care }\end{array}$ & $\begin{array}{l}\text { Helping wife to do domestic } \\
\text { activities } \\
\text { (n1) (n2) (n3) }\end{array}$ & $\begin{array}{l}\text { Before leaving for work, if the } \\
\text { wife is cooking and doing } \\
\text { housework, I will help to bath } \\
\text { and feed the child, later in the } \\
\text { afternoon or at night } \\
\text { accompanying the child until he } \\
\text { sleeps. }\end{array}$ \\
& $\begin{array}{l}\text { Accompanying children's play } \\
\text { activities (n1) (n2) (n3) }\end{array}$
\end{tabular}

The third category discusses fathers who attend seminars or organizations related to cerebral palsy. Participant (n1) stated that they have attended a seminar and applied or practised the knowledge gained during the seminar for their children. Fathers can play a role in various circumstances, including parenting and participation in activities. The policy previously focused on mothers began to provide opportunities and space for father figures to express themselves in the parenting process. However, because the father works to fulfil the family needs, some fathers are not actively involved in organizations or seminars (Hidayati et al., 2011). The existence of community and parental training programs will positively contribute to parents' knowledge and ways in implementing child care $(\mathrm{Hu}, 2010$; Lindsay, Proulx, Scott, \& Thomson, 2014; Mcintyre \& Phaneuf, 2017).

Table 5. Activities of fathers to increase knowledge related to $\mathrm{CP}$

\begin{tabular}{lll}
\hline Category 3 & Code & Quote \\
\hline $\begin{array}{l}\text { Father's activities to increase } \\
\text { knowledge related to CP }\end{array}$ & $\begin{array}{l}\text { Attending the Seminar } \\
\text { (n1) }\end{array}$ & $\begin{array}{l}\text { Yes, I attended a CP seminar } \\
\text { once. If any family gathering, } \\
\text { the CP family also always come } \\
\text { Attending a }\end{array}$ \\
\hline
\end{tabular}




$\begin{aligned} & \text { organization/union with } \mathrm{CP} \\ & \text { (n1) (n2) }\end{aligned}$
practised a little bit, for example
how to stretching

The fourth category considers the type of communication made by the father with the child. All the participants often ask about the child's activities for the whole day while the father is working. Sometimes fathers also take the opportunity to read a child a book. Fathers expected to be actively involved in direct interactions with children. Fathers involved in childcare since infancy positively affect their development(Kleemans, Peeters, Segers, \& Verhoeven, 2012; Paul et al., 2020).

Table 6. Type of communication between father and son

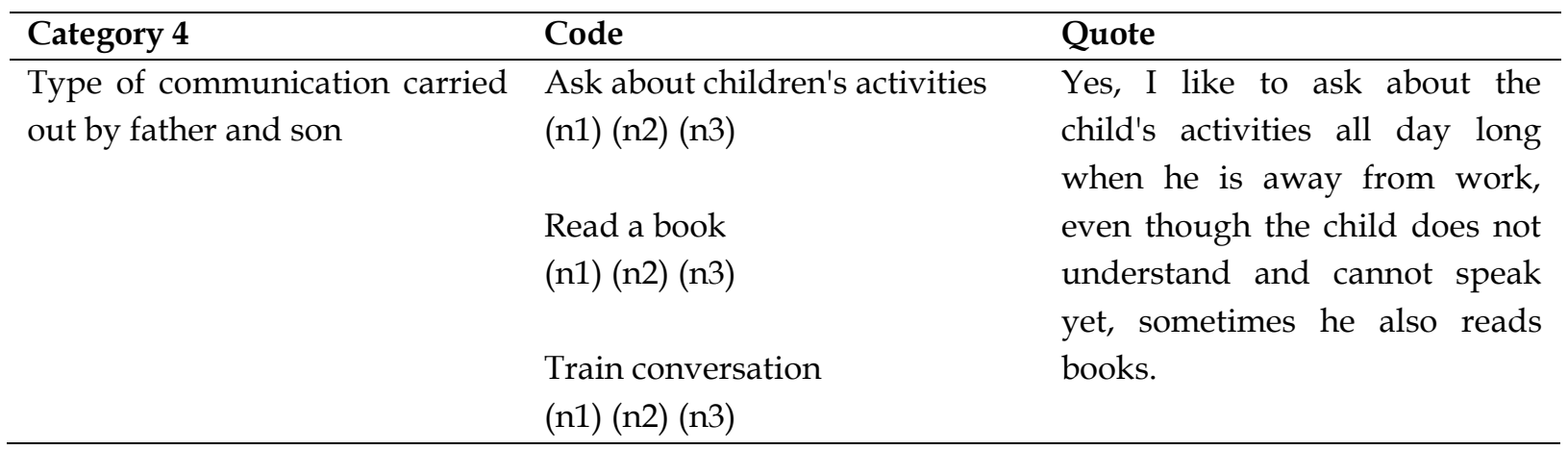

In the fifth category, it presents the father's involvement in fulfilling the child's daily necessities. Participants (n1, n2) show that fathers fulfil their children's needs by working because by working, they can fulfil their every need. Meanwhile, the participant (n3) was directly involved in fulfilling children's basic needs, such as giving milk, changing clothes, and diapers. People with cerebral palsy need treatment to meet their daily necessities (Ikasari \& Kristiana, 2017; Prasastiwi \& Hardjanta, 2017; Puspitarini, 2017; Septiningsih \& Cahyanti, 2014; Whittingham et al., 2013).

Table 7. The way the father is actively involved in fulfilling the daily needs of the child

\begin{tabular}{lll}
\hline Category 5 & Code & Quote \\
\hline $\begin{array}{l}\text { The way the father is actively } \\
\text { involved in fulfilling the daily } \\
\text { needs of the child }\end{array}$ & $\begin{array}{l}\text { Work } \\
(\mathrm{n} 1)(\mathrm{n} 2)\end{array}$ & $\begin{array}{l}\text { Yes, with work, so that we can } \\
\text { fulfil children's needs. }\end{array}$ \\
\cline { 2 - 3 } $\begin{array}{l}\text { Give milk, change clothes and } \\
\text { diapers for children } \\
(\mathrm{n} 3)\end{array}$ & $\begin{array}{l}\text { Yes, if you have free time or if } \\
\text { you're not working, sometimes } \\
\text { you come home from work to } \\
\text { help feed the child's milk, } \\
\end{array}$ & $\begin{array}{l}\text { sometimes change the child's } \\
\text { clothes + diapers }\end{array}$ \\
\hline
\end{tabular}

The sixth category discusses how fathers respond to people's judgments. All participants responded to people's comments to him by explaining if someone asked questions about their child's condition, not all parents accepted what people said 
about their children; many people commented irritably, but the three participants had better not to listen. People tend to think of them as disabled children who have no future (Megalonidou, 2020). Parents have an essential role in educating and caring for a child with cerebral palsy. The mother's role is needed, but a father's role is also essential (Keown \& Palmer, 2014; Putnick et al., 2012).

Table 8. How fathers respond to other people's comments

\begin{tabular}{lll}
\hline Category $\mathbf{6}$ & Code & Quote \\
\hline $\begin{array}{l}\text { The way dad responds to } \\
\text { other people's comments }\end{array}$ & $\begin{array}{l}\text { Do not care and explain if } \\
\text { asked (n1) (n2) (n3) }\end{array}$ & $\begin{array}{l}\text { Yes, if the person asks/comments, I will } \\
\text { explain well or just ignore it }\end{array}$ \\
\hline
\end{tabular}

The seventh category describes the way fathers educate their children. Participants teach their children to share (n3), sharing and discussing with each other (n1), and raising self-confidence (n2). Fathers are involved in providing children opportunities to do something, care, provide support and a sense of security. Children with fathers who are actively involved in parenting will have good cognitive and social abilities and have a high sense of trust (Aisyah et al., 2019; Appl et al., 2008; Astuti \& Masykur, 2015). The father's involvement also helps build empathy, love each other and have good social relationships with others (Allen \& Daly, 2007; Appl et al., 2008; Crespi \& Ruspini, 2015; Keown \& Palmer, 2014).

Table 9. How fathers teach their children with cerebral palsy

\begin{tabular}{|c|c|c|}
\hline Category 7 & Code & Quote \\
\hline \multirow[t]{3}{*}{$\begin{array}{l}\text { The way the father } \\
\text { teaches children } \\
\text { with cerebral } \\
\text { palsy }\end{array}$} & $\begin{array}{l}\text { Share to other } \\
\text { (n3) }\end{array}$ & $\begin{array}{l}\text { I teach children to share, for example, like } \\
\text { yesterday I got a Diapers } 4 \text { packages from other } \\
\text { and I said, "Sir, the pampers asked for } 1 \text { for the } \\
\text { older brother. Allowed or not?". Brother answered } \\
\text { "yes". }\end{array}$ \\
\hline & $\begin{array}{l}\text { Sharing and discussion } \\
\text { (n1) }\end{array}$ & $\begin{array}{l}\text { The way we teach us is almost the same because } \\
\text { we like to share discussions first. }\end{array}$ \\
\hline & $\begin{array}{l}\text { Raising Confidence } \\
\text { (n2) }\end{array}$ & $\begin{array}{l}\text { By asking him out and don't be embarrassed so } \\
\text { that the child becomes confident. }\end{array}$ \\
\hline
\end{tabular}

The eighth category is the father's method of quieting the child if something happens to the child. In participants (n3) the father promised a reward so that the child would stop crying, to participants $(n 1, n 2)$ by giving hugs and touches because according to the participants a hug was the most important. This method saw that when a father gives love to his children, the child will undoubtedly be close to his father, and the father's figure will grow to be a braver and more expressive person. Fathers will give more love and do their best to please their children (Keown \& Palmer, 2014). 
Table 10. The father's way of comforting the child

\begin{tabular}{llr}
\hline Category 8 & Code & Quote \\
\hline $\begin{array}{l}\text { The way the father } \\
\text { calms the child if } \\
\text { something happens } \\
\text { to the child }\end{array}$ & $\begin{array}{l}\text { Promised } \\
\text { reward }\end{array}$ & $\begin{array}{l}\text { At that time, my child cried. When I came home from } \\
\text { work I carried him and talked to him. When my child } \\
\text { wanted to stop crying, I promised him an ice cream. And } \\
\text { Alhamdulillah, my child stopped crying. }\end{array}$ \\
\cline { 2 - 4 } & $\begin{array}{l}\text { Give Hugs and } \\
\text { Touches } \\
\text { (n1) (n2) }\end{array}$ & $\begin{array}{l}\text { More to a hug, if suddenly confessed his body, I } \\
\text { immediately picked him up and hugged him. Because I } \\
\text { can't communicate verbally yet, so my touch is the most } \\
\text { important for him. }\end{array}$ \\
\end{tabular}

The ninth category considers the challenges that fathers face in caring for children with cerebral palsy. In participant (n3), the challenge experienced is that parents must continue to be enthusiastic in facing it when a child was getting unwell. Participants (n1) experienced many challenges, such as pursuing children's independence, fighting laziness to do routine therapy at home, and when the child was the hospital. In participants (n2), the child's challenges were when the child cried, and as parents did not understand what the child wanted. The role of parents in caring for cerebral palsy children is complicated. Children have imperfections, so they need help in carrying out activities. Parents' role is essential in bathing, take him to the therapy place, and help during the therapy process (Sakdiyah, 2012).

Table 11. Challenges faced by fathers in caring for cerebral palsy children

\begin{tabular}{|c|c|c|}
\hline $\begin{array}{l}\text { Category 9 } \\
\text { Challenges that } \\
\text { fathers face in } \\
\text { parenting children } \\
\text { with cerebral palsy. }\end{array}$ & Code & Quote \\
\hline \multirow{5}{*}{$\begin{array}{l}\text { Challenges that } \\
\text { fathers face in } \\
\text { parenting children } \\
\text { with cerebral palsy. }\end{array}$} & $\begin{array}{l}\text { When the child is } \\
\text { getting sick } \\
\text { (n3) }\end{array}$ & $\begin{array}{l}\text { The most difficult challenge in our life when our } \\
\text { child is sick. }\end{array}$ \\
\hline & Against laziness (n1) & $\begin{array}{l}\text { here are lots of challenges; the most challenging is } \\
\text { pursuing the child's independence, the challenge }\end{array}$ \\
\hline & $\begin{array}{l}\text { Teaching independence } \\
\text { (n1) }\end{array}$ & $\begin{array}{l}\text { of fighting laziness to treat children at home } \\
\text { routinely, the challenge of often going in and out } \\
\text { of the hospital, especially if the child has had }\end{array}$ \\
\hline & $\begin{array}{l}\text { When the child has a } \\
\text { seizure } \\
\text { (n1) }\end{array}$ & seizures \\
\hline & $\begin{array}{l}\text { Trying to understand } \\
\text { the character of the } \\
\text { child } \\
\text { (n2) }\end{array}$ & $\begin{array}{l}\text { Sometimes children with cerebral palsy often cry. } \\
\text { As parents, we do not understand what our } \\
\text { children want }\end{array}$ \\
\hline
\end{tabular}

the tenth category, it addresses the father's way of dealing with the challenges that occur. Each participant has their difficulties, but the focus of all their challenges is to be more sincere, patient, and accept God destiny. Every parent has their parenting challenges, especially parents who have children with special needs. Parents have a good acceptance in order to face these challenges (Dwairy, 2009; Fernández-García, Rodríguez-Menéndez, \& Peña-Calvo, 2017; Machado, Machado, Neves, \& Fávero, 2014; Meiza, Kardinah, Rahman, \& Puspasari, 2019; Putnick et al., 2012; Whittingham et al., 2013). 
Table 12. Father's way of dealing with challenges

\begin{tabular}{lll}
\hline Category $\mathbf{1 0}$ & Code & Quote \\
\hline $\begin{array}{l}\text { Father's way of } \\
\text { dealing with } \\
\text { challenges }\end{array}$ & $\begin{array}{l}\text { Sincere, } \\
\text { Accept } \\
\text { destiny } \\
(\mathrm{n} 3)\end{array}$ & More sincere, trying to accept God destiny. \\
\cline { 2 - 3 } & $\begin{array}{l}\text { Be patient } \\
\text { and } \\
\text { consistent } \\
\text { (n1) (n2) }\end{array}$ & $\begin{array}{l}\text { The main point of facing the challenges is patience because if you } \\
\text { can't wait, you will definitely give up, for example, after } 3 \text { years of } \\
\text { therapy, you still can't lift your head, if you can't wait, we will } \\
\text { definitely stop therapy, if you face laziness, the children at home will } \\
\text { return to our hopes. For one day our children can be independent. If } \\
\text { we are lazy, it is impossible to achieve our dreams. If we face a } \\
\text { seizure, we have to take care of the child's eating, which triggers us to } \\
\text { avoid seizures, consistently take the child's routine medicine, etc. }\end{array}$ \\
&
\end{tabular}

\section{Conclusion}

The discussion above concludes that the three participants are actively involved in caring for children with cerebral palsy. This result indicates that the three participants often help their spouses in their spare time by fulfilling their children's daily needs such as eating, giving medication, routine home therapy, bathing, and changing children's diapers. Participants also did many enjoyable activities with their children, such as playing, storytelling, and singing together. Each participant has difficulties carrying out or dealing with cerebral palsy children, but the participants think they should face those conditions with patience and sincerity. The participants felt a sense of heaviness to do child therapy, but what made them excited again was that their children's hopes were exceptional.

The limitation of this study is the researcher's depth of focus due to the limited time available. Besides, the relatively small number of participants still requires to explore more extensive and in-depth data. The description of fathers' involvement with children with cerebral palsy will be more comprehensive and in-depth if more participants are involved, and further research focuses on the varieties of father involvement.

\section{References}

Aisyah, D. S., Riana, N., \& Putri, F. E. (2019). Peran Ayah (Fathering) dalam Perkembangan Sosial Anak Usia Dini (Studi Kasus pada Anak Usia 5-6 tahun di RA Nurhalim Tahun Pelajaran 2018). Jurnal Wahana Karay Ilmiah_Pascasarjana (S2) PAI Unsika, 3(1), 294-304.

Allen, S., \& Daly, K. (2007). The Effects of Father Involvement: An Updated Research Summary of the Evidence. Guelph: Centre for Families, Work \& Well-Being, University of Guelph. http:/ / doi.org/10.1080/15295190709336777

Anindita, A. R., \& Apsari, N. C. (2020). Pelaksanaan Support Group Pada Orangtua Anak Dengan Cerebral Palsy. Focus: Jurnal Pekerjaan Sosial, 2(2), 208. http:/ / doi.org/10.24198/focus.v2i2.26248 
Appl, D. J., Brown, S., \& Stone, M. (2008). A father's interactions with his toddler: Personal and professional lessons for early childhood educators. Early Childhood Education Journal, 36(2), 127-134. http:/ / doi.org/10.1007/s10643-008-0263-2

Astuti, V., \& Masykur, A. M. (2015). Pengalaman Keterlibatan Ayah Dalam Pengasuhan Anak (Studi Kualitatif Fenomenologis). Jurnal Empati, 4(2), 65-70.

Cabrera, N. J., Tamis-LeMonda, C. S., Bradley, R. H., Hofferth, S., \& Lamb, M. E. (2000). Fatherhood in the twenty-first century. Child Development, 71(1), 127-136. http:/ / doi.org/10.1111/1467-8624.00126

Crespi, I., \& Ruspini, E. (2015). Transition to fatherhood: New perspectives in the global context of changing men's identities. International Review of Sociology, 25(3), 353-358.

Diadha, R. (2015). Keterlibatan Orangtua dalam Pendidikan Anak Usia Dini di Taman Kanak-Kanak. Edusentris, Jurnal Ilmu Pendidikan Dan Pengajaran, 2(1).

Dwairy, M. (2009). Parental Acceptance Rejection: A Fourth Cross-Cultural Research On Parenting And Psychological Adjustment Of Children. Journal of Child and Family Studies, 19(1), 30-35.

Dyches, T. T., \& Smith, T. B. (2017). Positive Parenting of Children with Developmental Disabilities : A Meta-Analysis.

Eliyanto, H., \& Hendriani, W. (2013). Hubungan Kecerdasan Emosi dengan Penerimaan Ibu Terhadap Anak Kandung yang Mengalami Cerebral Palsy. Jurnal Psikologi Pendidikan Dan Perkembangan, 2(2), 124-130.

Erawati, M. (2009a). Kajian metaanalisis 3 keterlibatan ayah dalam pengasuhan dan externalizing behavior pada anak. Indigenous, Jurnal Ilmiah Berkala Psikologi, 11(1), 2-19.

Erawati, M. (2009b). Model keterlibatan ayah dalam pengasuhan. Mudarrisa Jurnal Kajian Pendidikan Islam, 1(1).

Fernández-García, C.-M., Rodríguez-Menéndez, C., \& Peña-Calvo, J.-V. (2017). Parental control in interpersonal acceptance-rejection theory: a study with a Spanish sample using Parents' Version of Parental AcceptationRejection/Control Questionnaire. Anales de Psicología, 33(3), 652. http:/ / doi.org/10.6018/analesps.33.3.260591

Filus, A., \& Roszak, J. (2014). Relationships Between Parental Power, Prestige, and Acceptance, and the Psychological Adjustment of Young Adults in Poland. Cross-Cultural Research, 48(3), 286-294. http:/ / doi.org/10.1177/1069397114528458

Frank, T. J., Keown, L. J., \& Sanders, M. R. (2014). Enhancing Father Engagement and Interparental Teamwork in an Evidence-Based Parenting Intervention: A Randomized-Controlled Trial of Outcomes and Processes. Behavior Therapy, 46(6), 749-763. http:/ / doi.org/10.1016/j.beth.2015.05.008

Hidayati, F., Kaloeti, D. V. S., \& Karyono. (2011). Peran Ayah Dalam Pengasuhan Anak. Jurnal PSikologi Undip, 9(1), 1-10. http:/ / doi.org/10.26486/psikologi.v17i2.687

Hill, N. E., \& Craft, S. A. (2003). Parent-School Involvement And School Performance: Mediated Pathways Among Socioeconomically Comparable African American And Euro-American Families. Journal of Educational Psychology, 96, 74-83.

$\mathrm{Hu}$, B. Y. (2010). Training needs for implementing early childhood inclusion in 
China. International Journal of Early Childhood Special Education, 2(1), 12-30. http:/ / doi.org/10.20489/intjecse.107955

Ikasari, A., \& Kristiana, I. F. (2017). Hubungan antara Regulasi Emosi dengan Stres Pengasuhan Ibu yang Memiliki Anak Cerebral Palsy. Jurnal Empati, 6(4), 323328.

Jeong, H. M., \& Kim, H. Y. (2016). Factors Influencing Parental Satisfaction of Mothers with Preschool Children. Korean Journal of Women Health Nursing, 22(3), 117. http:/ / doi.org/10.4069/kjwhn.2016.22.3.117

Keown, L. J., \& Palmer, M. (2014). Comparisons between paternal and maternal involvement with sons: Early to middle childhood. Early Child Development and Care, 184(1), 99-117. http:/ / doi.org/10.1080/03004430.2013.773510

Kleemans, T., Peeters, M., Segers, E., \& Verhoeven, L. (2012). Child and home predictors of early numeracy skills in kindergarten. Early Childhood Research Quarterly. http:// doi.org/10.1016/j.ecresq.2011.12.004

Li, L., \& Fleer, M. (2015). Family pedagogy: parent-child interaction in shared book reading. Early Child Development and Care, 185(11-12), 1944-1960. http:/ / doi.org/10.1080/03004430.2015.1028398

Lindsay, S., Proulx, M., Scott, H., \& Thomson, N. (2014). Exploring teachers' strategies for including children with autism spectrum disorder in mainstream classrooms. International Journal of Inclusive Education, 18(2), 101-122. http:/ / doi.org/10.1080/13603116.2012.758320

Machado, M., Machado, F., Neves, S., \& Fávero, M. (2014). How Do Parental Acceptance-Rejection, Power, and Prestige Affect Psychological Adjustment? A Quantitative Study With a Sample of Portuguese College Students. CrossCultural Research, 48(3), 295-304. http:/ / doi.org/10.1177/1069397114528459

McFarland-Piazza, L., \& Saunders, R. (2012). Hands-on parent support in positive guidance: early childhood professionals as mentors. Australasian Journal of Early Childhood, 37(1), 65-73.

Mcintyre, L. L., \& Phaneuf, L. K. (2017). A Three-Tier Model of Parent Education in Early Childhood Applying a Problem-Solving Model. Topics in Early Childhood Special Education, 27(4), 214-222.

Megalonidou, C. (2020). The quality of early childhood education and care services in Greece. International Journal of Child Care and Education Policy, 14(1). http:/ / doi.org/10.1186/s40723-020-00074-2

Meiza, A., Kardinah, N., Rahman, A. A., \& Puspasari, D. (2019). Quantitative Profile of Family Acceptance of Children Special Need's Moslem Parents (Case Study at Rumah Terapi Aura). American Journal of Family Therapy, 47(4), 232-243. http:/ / doi.org/10.1080/01926187.2019.1635540

Miles, M. B., \& Huberman, M. a. (1994). Qualitative data analysis: An expanded sourcebook. Evaluation and Program Planning. http://doi.org/10.1016/01497189(96)88232-2

Moss, P. (2012). Caring and Learning Together: Exploring the relationship between parental leave and early childhood education and care. European Journal of Education, 47(4), 482-493. http://doi.org/10.1111/ejed.12003

Parmanti, \& Purnamasari, S. E. (2015). Peran Ayah dalam Pengasuhan Anak. Jurnal InSight, 17(2), 81-90. 
Paul, S. A. S., Hart, P., Augustin, L., Clarke, P. J., \& Pike, M. (2020). Parents' perspectives on home-based character education activities. Journal of Family Studies, 0(0), 1-23. http:/ / doi.org/10.1080/13229400.2020.1806097

Pradipta, R. F., \& Andajani, S. J. (2017). Motion Development Program for Parents of Child with Cerebral Palsy. Jurnal Penelitian Dan Pengembangan Pendidikan Luar Biasa, 4(2), 160-164.

Prasastiwi, B. H., \& Hardjanta, G. (2017). Penerimaan Diri Orangtua yang mempunyai Anak Cerebral Palsy. Jurnal Pemikiran Dan Penelitian Psikologi, 12(2), 100-107.

Puspitarini, Z. (2017). Hubungan antara Pengalaman Orang Tua dalam Perawatan Kualitas Hidup Anak Cerebral Palsy di Yogyakarta Tahun 2016. Jurnal Keperawatan Respati Yogyakarta, 4(1), 112-117.

Putnick, D. L., Bornstein, M. H., Lansford, J. E., Chang, L., Deater-Deckard, K., Di Giunta, L., ... Bombi, A. S. (2012). Agreement in Mother and Father AcceptanceRejection, Warmth, and Hostility/Rejection/ Neglect of Children Across Nine Countries. Cross-Cultural Research, 46(3), 191-223. http:/ / doi.org/10.1177/1069397112440931

Rohner, R. P. (2014). Parental Power and Prestige Moderate the Relationship Between Perceived Parental Acceptance and Offspring's Psychological Adjustment: Introduction to the International Father Acceptance-Rejection Project. CrossCultural Research, 48(3), 197-213. http:/ / doi.org/10.1177/1069397114528295

Rosenbaum P, Paneth N, Leviton A, et al. (2007). A report: the definition and classification of cerebral palsy April 2006. Dev Med Child Neurol Suppl, 49(6), 480.

Rovasita, S. (2017). Sharing Experience dan Resiliensi: Studi atas Facebook Group Orang Tua Anak Cerebral Palsy. Inklusi: Journal of Disability Studies, 4(1), 119. http:/ / doi.org/10.14421/ijds.040106

Sakdiyah, H. (2012). Penerimaan Orang Tua yang Memiliki Anak Penyandang Cerebral Palsy (Sebuah Studi Kasus). IAIN Surabaya.

Septiningsih, D. H. N., \& Cahyanti, I. Y. (2014). Psychological Well-being Ayah Tunggal Dengan Anak Penderita Cerebral Palsy. Jurnal Psikologi Klinis Dan Kesehatan Mental, 3(1), 50-58.

Siron, Y. (2019). Keterlibatan Orang Tua, Regulasi Diri, Agresivitas Mempengaruhi Perilaku Toleran Anak: Path Analysis. Awlady: Jurnal Pendidikan Anak, 5(1), 126149. http:/ / doi.org/10.24235/awlady.v5i1.3698

Siron, Y., Perdana, V. R., Saputri, S. R., \& Hanifah, D. N. (2020). Bagaimana Menjadi Orang Tua Anak dengan Cerebral Palsy? A Parent Acceptance (How to be Parent of Children with Cerebral Palsy? A Parent Acceptance). Atfaluna: Journal of Islamic Early Childhood Education, 3(2), 90-104.

Varan, A., Rohner, R. P., \& Eryuksel, G. (2008). Intimate partner acceptance, parental acceptance in childhood, and psychological adjustment among American adults in ongoing attachment relationships. Cross-Cultural Research, 42(1), 13-22. http:/ / doi.org/10.1177/1069397107309750

Whittingham, K., Sanders, M., McKinlay, L., \& Boyd, R. N. (2013). Stepping Stones Triple $\mathrm{P}$ and Acceptance and Commitment Therapy for Parents of Children with Cerebral Palsy: Trial Protocol. Brain Impairment, 14(2), 270-280. http:/ / doi.org/10.1017/BrImp.2013.19 
WHO. (2013). Birth Defects in South-East Asia A Public Health Challenge. Regional Office for South-East-Asia.

Yuliyati. (2014). Model budaya baca-tulis berbasis balance literacy dan gerakan informasi literasi di SD. Jurnal Ilmu Pendidikan, 20(1), 117-126. 